\title{
Business Opportunities for Halal Products in the Global Market: Muslim Consumer Behaviour and Halal Food Consumption ${ }^{1}$
}

\author{
Endang S Soesilowati \\ Center for Economic Research \\ Indonesian Institute of Sciences
}

\section{Introduction}

Halal products, halal confectionary and food ingredients, and the syariah system have attracted much attention among members of Organisation of the Islamic Conference (OIC) countries. It has been estimated that the trade value of halal products in the global market has reached more than \$US600 billion ${ }^{2}$ and the trade will keep increasing at 20 to 30 per cent annually ${ }^{3}$ The potential market for halal products is the world's Islamic population, which is of the order of 1600 million people. Of this total, Indonesia contributes 180 million; India, 140 million; Pakistan, 130 million; the Middle East, 200 million; Africa, 300 million; Malaysia, 14 million and North America, 8 million. ${ }^{4}$ Apparently, the availability of halal products is still limited; as a consequence, to meet consumer demand some Islamic countries have to even import halal goods from non-Muslim countries. For instance, Middle Eastern countries import halal meat from non-Muslim countries, especially

1 This paper is based on a research report of Center for Economic Research, 2009. The research team comprised Endang S Soesilowati, Jusmaliani, Umi Karomah, Yani Mulyaningsih and Diah Suhodo.

2 As mentioned by the previous Ministry of Agriculture, Anton Apriyantono, Antara News, 17 December 2007.

3 Stated by President Susilo Bambang Yudhoyono in the opening ceremony of the 3rd World Islamic Economic Forum, 'Islam and the Challenge of Modernization', Kuala Lumpur, Malaysia, 28 May 2007.

4 Indonesia International Halal Exhibition - Halal Indonesia, 2006. (http://www.mastic.gov. $\mathrm{my} / \mathrm{servlets} / \mathrm{sfs})$ 
from Australia and Brazil (Sungkar, 2007). It is, then, a lucrative market and there are huge business opportunities for halal food in the domestic and international markets.

As the world's most populous Muslim country, Indonesia has the potential to become not only a major market but also a major producer of halal products. Therefore the study will be a valuable aid to help assess Indonesian capability in seizing market opportunities in the global halal food trade.

Large numbers of Muslims do not always make the decision to buy halal food. Being a Muslim does not guarantee that an individual's behaviour will always be Islamic, especially in consuming halal foods. The philosophy and the implementation of Islamic syariah is, to some extent, constructed through individual learning and socialisation, that is, in formal and informal education. It is the religious education experiences that will also determine the level of awareness of halal food consumer behaviour.

The result of the study of the behaviour of halal food consumers is expected to give valuable insight and knowledge and to help forecast the demand for halal food, as well as to help formulate an appropriate market strategy for halal food entrepreneurs. If Indonesia is to increase its economic growth by investing in and developing halal products, it will require a study of Muslim behaviour as consumers of halal products. To what extent Indonesian Muslims are concerned with halal products is not known yet. It was interesting to study what are the criteria for assessing halal foods in terms of consumer perceptions, whether halal refers only to the food's content or does it also include food preparation and so on. Furthermore, it will be valuable to discover the extent to which the degree of religiosity determines the awareness of halal food and affects consumer behaviour.

\section{Literature Review}

Consumer behaviour, like any other behaviour, is affected by cultural, social, personal and psychological characteristics. Cultural factors are 
assumed to be dominant in influencing the intentions and behaviours of consumers. It is claimed in some of the literature that religion is the key cultural element that determines behaviour and decisions to buy (Assadi, 2003; Esso and Dibb, 2004; Delener, 1994; Babakus, 2004; Cornwell, 2005). Cited Cloud (2000), Fam et. al (2004) stated that a religion can be described as '...the habitual expression of an interpretation of life, which deals with ultimate concerns and values. Institutional religion formalises these into a system which can be taught to each generation' 'Islam is more than a religion as it controls the ways of society and factors associated with family, dress, cleanliness and ethics' (Fam, 2004). A religious person has a value system that differs from an unreligious person.

Meanwhile, religiosity is the extent of a person's commitment to his or her religion (cited Johnson et al., 2001, Mokhlis (2006). Religiosity is very important because it determines individual cognition and behaviour (Sitasari, 2008). It is highly likely that religiosity will govern an individual's behaviour, including behaviour as a halal food consumer.

A religion may influence consumer behaviour and behaviour in general (Delener, 1994, Pettinger, 2004), especially in decisions to buy meals and in establishing food habits (Bonne, 2007). As also stated by Schiffman and Kanuk (1997), is that decisions to buy are dependent on religious identity (cited in Shafie and Othman, 2006). Religious control of food consumption patterns is in terms of restrictions on particular foods: Jews, for example, are prohibited from eating pig meat; and beef is prohibited for Hindus. Muslims are prohibited from eating pork, blood, and animals that have not been killed in the way prescribed by syari 'ah law, and they may not drink alcoholic beverages. Muslims have a religious obligation to consume halal food (Bonne et al., 2007).

Because this study focuses on consumer behaviour of Muslims in relation to halal food, a theory of planned behaviour is used as a conceptual framework. The theory of planned behaviour (Ajzen, 1991) proposes that there are at least three dominant factors influencing behaviour; attitude, subjective norm, and perceived behavioural control (see Diagram 1). 
Attitude is a psychological propensity to evaluate whether something is liked or disliked. It is an individual's positive or negative evaluation of self-performance of a particular behaviour. A subjective norm is an individual's perception of social pressure of what to do or not to do. At this level, the culture of the society people live in may control their behaviour. A perception of behavioural control is an individual perception to the extent that particular behaviour would be controlled. The extent to which an individual understands and follows his or her religion is a perception that may control their behaviour.

Diagram 1: Conceptual Framework of Consumer Behaviour

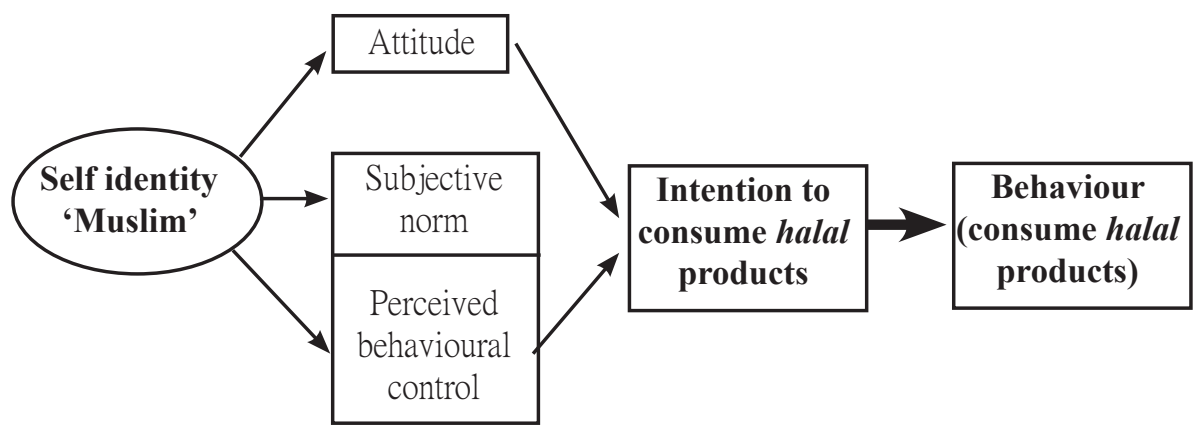

Source: Adapted from Ajzen (1991)

These three factors (attitudes, subjective norms, and perceived behavioural control) will determine individual intentions to consume halal food and will be shown in their consumption behaviour. The intention is a motivational situation prior to behaviour and it indicates an individual's readiness to perform a given behaviour.

Although religion mandates strict laws in terms of food consumption, the extent to which its adherents follow those halal laws is highly likely to vary (Bonne, 2007) and this variation will be affected by those three dominant behavioural factors that are listed in the previous paragraph. The degree to which an individual is religious, that is, their religiosity, is part of their self-identity as a Muslim, and to that extent they will have Muslim attitudes, subjective norms and perceived behavioural control 
that determines their intention to consume halal foods. However, the extent to which an individual consumes halal food will also depend on other related factors, such as availability of halal food, chance, knowledge, and sources including money.

\section{Research Methods}

This research is to analyse Muslim consumer behaviour in regard to halal food, especially the behaviour of those who live in urban areas. The study will also examine how different degrees of religiosity might affect consumer behaviour. Quantitative methods were mainly used, that is, gathering primary data by surveying a hundred Muslim respondents in Banten, an area chosen because it has a predominantly Muslim population.

A structured Likert-scale questionnaire in self-report form was used in this study; the respondents were asked directly about their knowledge, attitudes, beliefs and feelings about particular objects or activities (Churchill, 1995). To get more comprehensive data, the study also used qualitative methods; conducting in-depth interviews with several key persons and religious leaders in the field.

To measure the behaviour of consumers of halal food, a number of variables were selected, including level of education, religious education background (pesantren or other), understanding of halal products, socioeconomic strata, and gender. The SPSS program was used for data entry and to analyse the data gathered through questionnaires. To get more meaningful findings, comparisons between groups of respondents and variables were applied using the analyses technique. The comparisons were of the average scores of group respondents or variables that are usually known as the cut off point (COP). Descriptive analyses in the form of graphics, cross tabulation, and simple statistical techniques were also applied to examine the correlation between the variables. 


\section{Research Findings}

This research found several major issues that showed relatively interrelated factors influencing Muslim behaviour in their consumption of halal foods. First, the research found that the awareness of Muslims in Banten concerning halal and haram food was considerably high, especially in selecting foods that need to be further processed before they are eaten, items such as meat, fish and vegetables. They consistently put a high priority on the halal issue when they purchase food, buy meat, or select a restaurant.

Second, the role of government to promote and control religious behaviour in terms of halal food consumption was considered slightly insensitive Most respondents claim that the religious laws of conduct and religious leaders force their decision to consume halal food.

Third, a Pearson correlation score, between the degree of individual religiosity and halal food consumption shows that the higher the degree of a respondent's religiosity, the greater their concern to consume halal food $(r=0.565)$. Because the degree of respondents' religiosity was also influenced by their religious experience and education background, respondents with a pesantren education tended to have more control and concerns about their halal food consumption. However, the correlation score of education level and halal food consumer behaviour was extremely weak $(\mathrm{r}=0.012)$, which means there is no parallel relation between a respondent's education and their predisposition to consume halal food. It does not follow that the higher an individual's education, the more will be their concern to ensure that the food they eat conforms to halal requirements. In addition, it (the predeliction for halal food) was not dependent on the degree of a respondent's religiosity; the respondents tended first to control and ensure their family ate halal food before any other related religious obligations. It was a striking feature that those who had the highest degree of religiosity were highly likely to remind their religious leaders of their obligations to consume halal food.

Fourth, the most important criteria for halal food for Muslim respondents in Banten are that their food must free of pig meat and alcohol; the halal 
certificate from the Majlis Ulama Indonesia (MUI) [Indonesian Ulama Council] was not so important. ${ }^{5}$ However, numbers of respondents still believe that the halal label on food packaging and in restaurants is important. The halal label from the MUI was more trusted than any other halal label. The long process and procedures in obtaining halal certification were considered costly, and because of this, small and medium businesses were reluctant to register their products. Most respondents declared that the higher prices of halal products would not lessen the amount of their purchases of halal food products.

Although it was sensed by Muslims in the Banten area that the role of the MUI in the Banten region tends to be limited, and that it tends to have poor coordination with the Health and the Religious Affairs Departments concerning halal matters, and that there is disagreement between the MUI and the Religious Affairs Department about which institutions may issue halal certificates - despite all these causes for misgivings, several respondents' enthusiasm for the MUI's halal endorsement and labels was not diminished when it came to selecting and buying halal foods.

Finally, to measure and understand how aware Banten Muslims were of halal food consumption, researchers tried to examine the effectiveness of attitudes, subjective norms, and perceived behavioural control on the food consumption patterns between groups of respondents based on two kinds of COP. The first COP was calculated from the average of those three dominant behavioural factors (consisting of 21 variables), and the second COP was derived from the average of total variables (covers 84 variables). The first COP score was 5.807, and the second COP score was 5.890 .

5 MUI is an institution authorised to publish halal certificates in Indonesia. 
Table 1

Comparison of three dominants behavioural factors COP by segment of respondents

\begin{tabular}{|c|c|c|c|c|}
\hline Segment of Respondent & Attitudes & Subjective norms & Perceived control & $\begin{array}{c}\text { Respondents } \\
(\%)\end{array}$ \\
\hline \multicolumn{5}{|l|}{ Income } \\
\hline Lowest income & 5.962 & 5.619 & 5.667 & 22 \\
\hline Lower income & 6.422 & 5.333 & 6.104 & 38 \\
\hline Middle income & 6.422 & 5.868 & 6.236 & 19 \\
\hline Higher income & 6.417 & 4.469 & 6.052 & 13 \\
\hline Highest income & 5.467 & 4.194 & 5.458 & 9 \\
\hline \multicolumn{5}{|l|}{ Type of work (profession) } \\
\hline Teacher & 6.593 & 5.117 & 6.367 & 27 \\
\hline Employee & 5.929 & 5.085 & 5.677 & 31 \\
\hline Trader & 6.200 & 5.702 & 6.038 & 12 \\
\hline Housewife & 6.412 & 5.868 & 6.176 & 2 \\
\hline Others & 5.911 & 5.056 & 5.042 & 17 \\
\hline \multicolumn{5}{|l|}{\begin{tabular}{|l|} 
Age Group \\
\end{tabular}} \\
\hline Below 26 & 6.920 & 5.850 & 6.450 & 5 \\
\hline 26 to 35 & 6.165 & 5.143 & 5.776 & 34 \\
\hline 36 to 45 & 6.344 & 5.160 & 5.969 & 36 \\
\hline 46 to 55 & 6.056 & 5.736 & 5.993 & 18 \\
\hline Over 55 & 6.114 & 5.339 & 6.357 & 7 \\
\hline \multicolumn{5}{|l|}{ Education } \\
\hline Elementary & 6.467 & 5.792 & 6.417 & 3 \\
\hline Junior High School & 5.880 & 5.788 & 6.013 & 10 \\
\hline Senior High School & 6.029 & 5.475 & 5.686 & 35 \\
\hline Diploma (D1 - D3) & 6.067 & 4.458 & 5.125 & 3 \\
\hline First grad (S1) & 6.452 & 5.052 & 6.152 & 46 \\
\hline Post grad (S2) & 6.733 & 5.958 & 6.375 & 3 \\
\hline \multicolumn{5}{|l|}{ Gender } \\
\hline Male & 6.130 & 5.085 & 5.802 & 63 \\
\hline Female & 6.438 & 5.679 & 6.226 & 37 \\
\hline \multicolumn{5}{|l|}{$\begin{array}{l}\text { Religious Educational } \\
\text { Background }\end{array}$} \\
\hline Non-Pesantren & 6.000 & 5.438 & 5.701 & 46 \\
\hline Pesantren & 6.452 & 5.192 & 6.178 & 54 \\
\hline Average Score (COP) & 6.244 & 5.305 & 5.959 & 100 \\
\hline
\end{tabular}

Source: Analyses primary data, P2E team, 2009 
Table 1 illustrates the comparison of those three factors by each segment group of respondents. The score that was higher than the first COP is in italic, and for that higher than the second COP is in bold. It is clearly seen that the subjective norms, which demonstrate the social pressure on the Muslims of Banten to consume halal food, was slightly weak. Unlike the subjective norm, the attitude and perceived behavioural control COP scores were adequately high (> 5.890).

Although, with closer observation, it can be seen that the only one cell in the table of respondents in the higher income group has neither italic nor bold. It can be inferred that the highest social level of Muslims in Banten tend to have less concern on halal consumption behaviour compared with other social groups. In contrast, respondents with higher education, middle class incomes, housewives, and younger age groups tend to be relatively more concerned to consume halal food; not only is this determined by their attitudes, but also by their subjective norms and perceived behavioural control.

\section{References}

Ajzen, I. (1991). 'The theory of planned behavior'. Organizational Behavior and Human Decision Processes, 50: 179-211.

Antara News (2007). 'Deptan dorong kembangkan kawasan industri produk halal'. Antara News, 17 December 2007. (http://www.antara.co.id/view/ $? \mathrm{i}=1197903396 \& \mathrm{c}=\mathrm{EKB} \& \mathrm{~s}=$ )

Assadi, Djamchid. (2003). 'Do religions influence customer behavior? Confronting religious rules and marketing concepts'. Cahiers $d u$ CEREN 5: 2-13.

Babakus, Emin and T Bettina Cornwell, Vince Mitchell, Bodo Schlegelmilch. (2004). 'Reactions to unethical consumer behavior across six countries'. Journal of Consumer Marketing, 21(4): 254-263.

Bonne, Karijn and Wim Verbeke. (2006). Muslim consumer's motivations towards meat consumption in Belgium: qualitative exploratory insights from meansend chain analysis. (http://aof.revues.org/document90.html)

Churchill, GA. (1995). Marketing research: methodological foundations. 6th ed. Fort Worth, Dryden Press.

Cornwell, Bettina and Charles Chi Cui, Vince Mitchell, Bodo Schlegelmilch, Anis Dzulkiflee, Joseph Chan. (2005). 'A cross-cultural study of the role of religion in consumers’ ethical positions’. International Marketing Review, 22 (5): 531-546. 
Delener, Nejdet. (1994). 'Religious contrasts in consumer decision behaviour patterns: their dimensions and marketing implications' (Abstract). European Journal of Marketing, 28 (5): 36-53.

Esso, Nittin and S Dibb. (2004). 'Religious influences on shopping behaviour: an exploratory study'. Journal of Marketing Management, 20 (7-8): 683-712.

Fam, K.S., Waller, D.S., \& Erdogan, B.Z. (2004). The Influence of Religion on Attitudes towards the Advertising of Controversial Product, European Journal of Marketing, 38(5/6): 537-555.

Mokhlis, Safiek. (2006). The Effect of Religiosity on Shopping Orientation: an exploratory study in Malaysia. Journal of American Academy of Business, 9 (1): 64-74.

Pettinger, C and M Holdsworth, M Gerber. (2004). 'Psycho-social influences on food choice in Southern France and Central England'. Appetite, 42 (3): 307-316.

President Speech. (2007). Special Keynote Address of President Susilo Bambang Yudhoyono at the opening ceremony of the 3rd World Islamic Economic Forum: Islam and the Challenge of Modernization in Kuala Lumpur, Malaysia, 28 May 2007. (http://www.presidensby.info/index.php/pidato/2007/05/28/655. html)

Shafie, S and NMd Othman. (2006). 'Halal certification: an international marketing issues and challenges'. (http://www.ctw-congress.de/ifsam/download/track 13/ pap00226.pdf)

Sitasari. (2008). 'Preferensi atribut dan perilaku konsumen kartu kredit syariah'. Laporan Tesis, PSTTI-UI

Sungkar, Irfan. (2007). Livestock Asia 2007 Exhibition \& Seminar Halal Hub Session; 25 October 2007. Kuala Lumpur (http://www.livestockasia.com/conference paper/slide/irfan.pdf) 